\title{
Improving Science, Technology and Mathematics Education in Nigeria: A Case Study of Obafemi Awolowo University, Ile-Ife
}

\author{
Sofowora Olaniyi Alaba ${ }^{1, *} \&$ Bimbo Adekomi ${ }^{1}$ \\ ${ }^{1}$ Department of Educational Technology, Obafemi Awolowo University, Ile-Jfe, Nigeria \\ *Corresponding author: Department of Educational Technology, Obafemi Awolowo University, Ile-Ife, Room 205, \\ Ile-Jfe, Osun State, Nigeria. E-mail: oasofowora@oauife.edu.ng/oasofowora@yahoo.com
}

Received: July 5, 2012

Accepted: August 5, $2012 \quad$ Online Published: November 20, 2012

doi:10.5430/wje.v2n6p13

URL: http://dx.doi.org/10.5430/wje.v2n6p13

\begin{abstract}
The study assessed the impact of a World Bank Assisted Project "STEP-B" on teaching and learning of Science, Technology and Mathematics Education (STM) in Nigeria. It also described the contribution of Obafemi Awolowo University, Ile-Ife to the improvement of STM through research development, utilization of ICT, human resources and Educational Technology infrastructure in Post Basic Education Institutions (PBEIs) in Nigeria. A sample of 360 participants was used. They were selected from all the PBEIs through stratified sampling technique based on gender, course, department, unit and job prescription. Data was collected using a-34 item questionnaire designed by the researcher with six sections. The data was analyzed using descriptive and inferential statistics. The results revealed that there was a remarkable improvement in the teaching and learning of STM in PBEIs $\left.\left(\mathrm{F}_{(4,233}\right)=6.112, \mathrm{P}<0.00\right)$. A new creative, participatory and competency based learning method that is flexible, robust that incorporate web-based instruction $\left(\mathrm{F}_{(4,235)}=2.248, \mathrm{p}<0.04\right)$ was used. There was an increase in female enrolments in STM as a result of the different motivation and sensitization workshops $\left.\left(\mathrm{F}_{(4,231}\right)=8.109, \mathrm{p}<0.01\right)$. The project was effective in building staff and students capacity to utilize WBLS $\left(\mathrm{F}_{(4,234)}=5.569, \mathrm{p}<0.01\right)$. There was also a reduction in the drop-out and failure rates among female students $\left(\mathrm{F}_{4,233)}=7.360, \mathrm{p}<0.05\right)$.
\end{abstract}

Keywords: Science and Technology in Post-Basic Education (STEP-B); PBEIs (Post Basic Eduction Institutions); STM (Science, Technology and Mathematics); CBT; (Competency Based Training); Web- Based Learning Systems and gender disparity

\section{Background}

Nigeria is one of the African largest $\left(923,768 \mathrm{~km}^{2}\right)$ countries and the most populous countries with an estimated population of 155,215,573 million as at 2009. Apart, it is one of the richest African counties. However, one of the major challenges militating against its growth and development is the challenge of providing quality education to its qualified youths. The problems facing the education sector include poor performance of students in national and international examinations especially in Science, Technology and Mathematics (STM). Others include non conducive teaching and learning environment, inadequate facilities and equipment for teaching and learning in PBEIs, and lack of legal backing and absence of good quality control system. According to Egwu (2009) other problem is poor staffing with difficulty to attract and retain young talents in the teaching profession. Out of a total of 180,546 teachers in the Secondary Schools only 141, 517 are qualified, leaving almost 39,023 unqualified (p.42). The above have serious implication for the development and teaching of Science, Technology and Mathematics Education in Nigeria. It is a popular axiom that STM has important role to play in the development of a nation that is willing to develop technological and scientific breakthrough. While many developed countries like Japan, China, Russia and United States of America have made remarkable development in the areas of Science, Technology Education and Mathematics (STM), Nigeria is just beginning to wake up to its responsibility of providing quality STM Education. 


\section{Problems Associated with Science, Technology and Mathematics (STM) in Nigeria}

There have been several authors that have researched into the problems associated with students' performance in STM. Prominent are Ajewole and Owolabi (1995), Okebukola (2007), Obomanu and Adaramola (2011) but none have adopted the present intervention of STEP-B. The major challenges identified by STEP-B include: gender disparity, inadequate exposure to practical and basic experiments. Poor method of teaching with too much emphasis on traditional method of teaching which does not provide competency based training to accommodate the new rapidly changing skills in a changing economy. (Togonu-Bickersteth 2008).

Egwu (2009) also supporting this claim says, the inadequacy and obsolete equipment as well as poor library facilities have adverse consequences on the quality of teaching and learning. This seeming poor performance and poor quality of prospective entrants into tertiary institutions have no doubt affected student's enrolment into STM. Egwu (2009) further lamented the current rate of admission of 6\% into tertiary institutions as against the accepted minimum of $16 \%$ for meaningful economic development. It is against this background that STEP-B project (Science and Technology Education at Post-Basic Institutions) in Nigeria was conceived.

\section{The Birth of STEP-B in Nigeria}

STEP-B is an innovative project designed by the Federal Ministry of Education with the support of World Bank in collaboration with the International Development Agency (IDA). It was declared effective on February 2008 and officially launched in Nigeria on Tuesday, $7^{\text {th }}$ October, 2008 in Abuja. It is a project aimed at improving teaching and learning of Science and Technology in Post-Basic Education Institutions.The project is also in line and in support of the call by SITE (Society for Information Technology and Teacher Education) to integrate technology into teaching and learning in this $21^{\text {st }}$ Century. According to the official bulletin of STEP-B (FME 2008) the project has 2 main broad goals relating to research and education:

(1) produce more better qualified S\&T teachers and graduates in the PBEIs;

(2) that all the PBEIs should be able to produce higher quality and more relevant research findings in S\&T.

\section{The Turn around Strategies for Achieving these Goals}

The following are the strategies that are to be adopted:

- $\quad$ increase the number of students trained in S\&T related courses;

- $\quad$ improve the teaching and learning of S\&T using a more creative, participatory and competency-based learning that utilizes Web-Based Learning System (WBLS);

- improve the quality of publications, research collaborations between public, private sectors and others institutions using transnational and international collaboration;

- $\quad$ reconceptualize S\&T curriculum to make it relevant to the needs of Nigeria (p.5)

The above strategies are in line with the strategic objectives of the Nigerian National Policy on Information Technology (NNPIT) and the Millennium Development Goals(MDGs) on education that have consistently encourage the integration, development, promotion and dissemination of research and professional knowledge in ICTs through project, conferences and workshops to improve education and to enhance sustainable development.The impact of which is being felt world wide and mostly in Nigeria.

\section{The Participating Institutions}

Those eligible to take part in the project are:

- $\quad$ post-Basic Education Institutions (PBBIs),

- $\quad$ Non Governmental Organizations partnering with PBEIs,

- research Institutions,

- $\quad$ group of researchers supported by a PBEI, and

- $\quad$ individuals supported by a PBEI (FME 2008) 


\section{Obafemi Awolowo University and Step-B}

Obafemi Awolowo University (OAU) Ile-Ife having the best ICT infrastructure in Nigeria worn the proposal to implement the project in Nigeria. According to Togonu-Bickersteth (2008) in the sub-component IB of the project, the new innovative approach is to address the followings:

- $\quad$ strengthening ICT facilities at OAU Ile-Ife and among the partnering institutions to provide greater access to S\&T programmes at post Basic Educational Institutions (PBEIs),

- $\quad$ it is also to bridge the gender gap in the enrolment of female students in S\&T (p.2).

\section{Collaborating Institutions}

The post Basic Educational Institutions (PBEIs) used includes:

- The Federal Polytechnic Ede,

- Adeyemi College of Education, Ondo,

- Obafemi Awolowo University International School, Ile-Ife, and

- $\quad$ Federal Science and Technical College, Ilesa.

\section{The Project Deliverables}

In order to ensure the timely achievement of the goals, the followings deliverables were implemented:

- $\quad$ upgrading of ICT and Educational Technology infrastructure at OAU Ife and in all the PBEIs.

- establishment of online library access in all the partnering PBEIs and the establishment of virtual laboratory in OAU for remote experimentation,

- recording, production and delivery of a Web-Based Learning System (WBLS) for Senior Science Students,

- $\quad$ capacity building for students and staff of OAU Ile-Ife and the partnering PBEIs through specialized workshops, general sensitization, staff development and training/study tours.

- $\quad$ motivating female students in S\&T.

A closer look at the above deliverables show that these goals are relevant to the aims and aspirations of the Society for Information Technology and Teacher Education(SITE) especially the 2011 and 2012 Conference Themes.

\section{Expected Outcomes of STEP-B}

Based on STEP-B Proposal Handbook (2008), the expected outcomes include enhanced teaching of Mathematics at the post basic level, improved staff capacities in the development and delivery of ICT-driven instruction. Increase number of student's enrolment in Bachelors, Masters and Doctoral Programmes in STM. Improve teaching and learning methods by using mordern approaches like activity based learning using ICT and educational Technology infrastructures (virtual laboratory, Science/Technology Museum, robotics, games and/simulations). Enhance students performance in STM with more students obtaining grade B. Apply the new emerging technologies in OAU and in teaching STM in all the partnering PBEIs and finally, establish new collaboration both nationally and internationally with other designated institutions and industries. This project has been in existence since 2008 perhaps, it is essential to assess its impact on the participating PBEIs and how the exposure/ and collaboration with SITE have impacted the success or ortherwise of the STEP-Bproject

\section{Research Purpose}

The main purpose of this study therefore is to assess the impact of the project on the participants and the extent to which it has enhanced the application of modern technology in learning in the $21^{\text {st }}$ Century. The study also assessed the extent to which OAU Ile-Ife have successful used technology in teaching and learning in the $21^{\text {st }}$ century. 


\section{Research Objectives}

This study is set out to achieve the following objectives:

(i) investigate the extent to which OAU STEP B has implemented the project policies,

(ii) assess the level of implementation of the two goals as it relates to education and research,

(iii) assess the impact of STEP-B project in enhancing web-based instruction in S\&T in the partnering PBEIs,

(iv) find out the future direction of the development in S\&T in the University

\section{Research Hypotheses}

(i) The STEP-B programme did not significantly enhance high quality Science/Technology graduate.

(ii) The programme did not enhance high quality research work in the University.

(iii) Students ICT capacity was not enhanced.

(iv) There is no significant improvement in the teaching and learning of mathematics even after the STEP-B project.

(v) The new project did not significantlt enhance the motivation level of female students in STM

(vi) There was no significance difference in the level of failure and drop-out rates among the female students in the University.

(vii) The project did not significantly enhance staff/ students capacity to utilize web-based instruction

\section{Methodology}

The study employed descriptive and case study research design. The population for the study consist all students in all the partnering Post Basic Education Institutions (PBEIs) in Osun and Ondo States. While a sample of 360 participants was selected using stratified sampling technique based on gender, unit, department, course of study and job. A 34 item questionnaire was developed and used for data collection. It was validated for content and construct validity. A reliability coefficient of 0.86 was obtained using Duncan test. The questionnaire was divided into six sections dealing with demography of sample, policy strategies, technology support learning, STEP-B and its impact on teaching STM, level of implementation as it relates to education and research. The data collected was analyzed using inferential statistic (One-Way Analysis of Variance).

\section{Findings and Discussions}

With respect to the extent of implementing the STEP-B strategic policies, find the data obtained in Table 1.

Table 1: Analysis of Variance on Implementation of STEP-B Project in S\&T

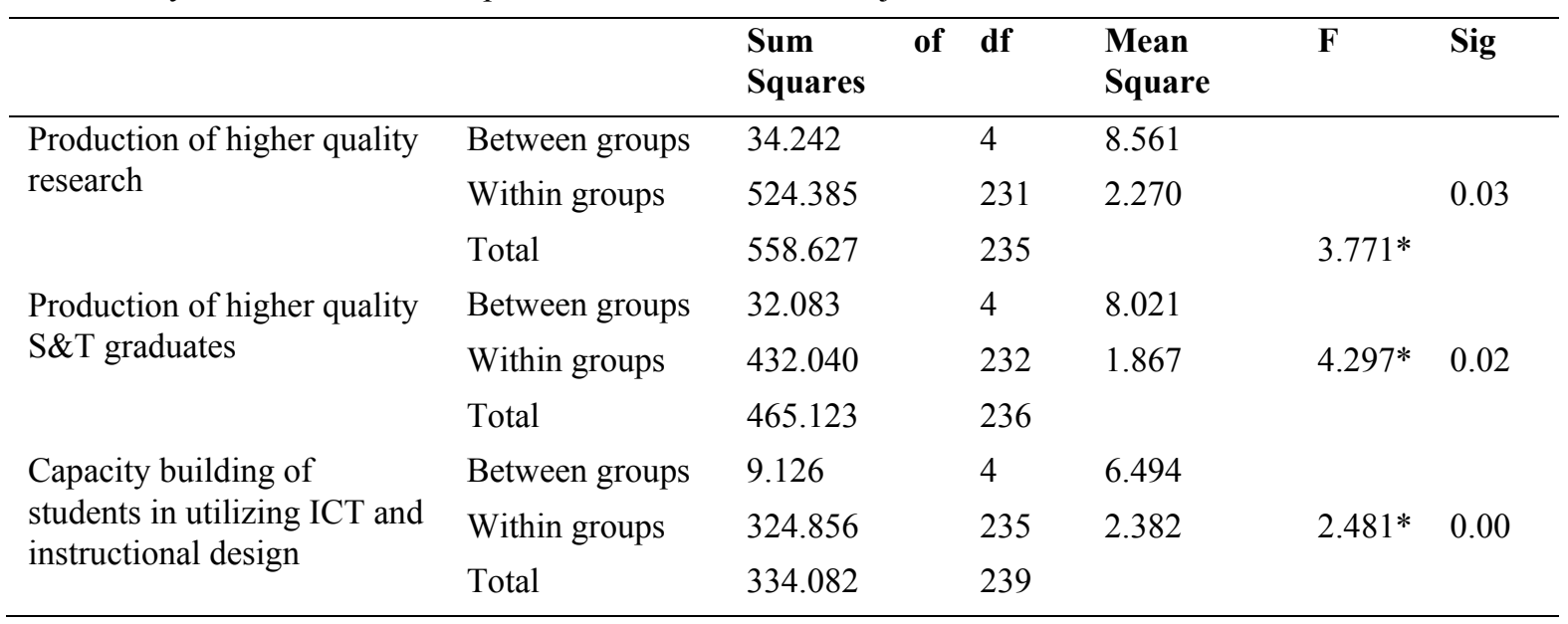




\begin{tabular}{lllllll}
\hline Provision of online & Between groups & 5.976 & 4 & 7.036 & & \\
library/internet access & Within groups & 286.320 & 235 & 1.218 & $3.676^{*}$ & .003 \\
& Total & 292.296 & 239 & & & \\
Improving teaching and & Between groups & 47.209 & 4 & 11.802 & & \\
learning mathematics & Within groups & 449.900 & 233 & 1.931 & $6.112^{*}$ & 0.00 \\
& Total & 497.109 & 237 & & & \\
Motivating female students & Between groups & 59.699 & 4 & 14.925 & & \\
in S\&T & Within groups & 425.182 & 231 & 1.841 & $8.109 *$ & 0.05 \\
& Total & 484.881 & 235 & & & \\
\hline
\end{tabular}

In order to assess the extent of implementation of STEP B project five areas were focused production of higher quality research studies, capacity building, training, infrastructute in S\&T the result showed that $F=3.771$ which was significant at 0.03 level. On production of higher quality STM graduates, the F calculated was 4.297 at 0.02 levels. It implies that between years 2008 to date, there were more graduates in STM in the PBEIs than the previous years. Hence the hypothesis that stated that the STEP-B project did not significantly enhance high quality research was rejected. All the results of the data analysis across all the PBEIs revealed that between 2008 and the present; there was remarkable improvement in STM when compared with the pre-STEP-B project era.

\section{STEP B and its Impact at Enhancing Web-Based Instruction in S\&T}

One of the laudable objectives of STEP-B that is similar to the International Society for Technology in Education (ISTE) and Society for Information Technology and Teacher Education (SITE) is the motivational use of ICTs and modern technologies to enhance teaching and learning in the $21^{\text {st }}$ Century. In order to do this, STEP-B introduced a more participatory, active and competency-based methodology that is flexible, robust and accommodate web-based instructions. To make this possible, The Carnegie Corporation Intervention fund was used to upgrade the ICT facilities by improving the Bandwidth from 512/256kbps to 5.0 mbps.

\section{Staff Training/Faculty Development and ICT Competency}

According to Togomu-Bickersteth (2008) staff/students competency is pivotal to the success of the scheme, in this context a general sensitization career talk and workshops including study tours were organized for faculty staff, students and other people from all the PBEIs to see how they have successfully used ICT and mordern technology in developing creativity in science and technology. Study tours to China, Massachusetts Institute of Technology (MIT) New York, African Virtual University Kenya and Israel were also organized for core staff that was also to retrain other staff in all the PBEIs.Others include exposure to SITE Conferences and workshops(2009 to date) This is with a view to building the ICT capacity of all the stakeholders. In order to assess the impact of all these on the sample, four general areas were assessed:

(i) effort at building staff and end users capability at using WBLS,

(ii) production and delivery of WBI,

(iii) upgrading ICT and Educational Technology infrastructure for STM and,

(iv) effect of all these efforts at reducing drop out/failure rates in STM among females (See table II) 
Table 2: Analysis of Variance of STEP-B and Its Impact at Enhancing WBLS

\begin{tabular}{|c|c|c|c|c|c|c|}
\hline & & $\begin{array}{ll}\text { Sum } & \text { of } \\
\text { Squares }\end{array}$ & Mean Square & df & $\mathbf{F}$ & Sig \\
\hline \multirow{4}{*}{$\begin{array}{l}\text { Building } \\
\text { staff/students } \\
\text { capacity in Web } \\
\text { Based Instruction }\end{array}$} & \multirow{2}{*}{$\begin{array}{l}\text { Between } \\
\text { groups }\end{array}$} & 15.970 & 3.992 & 4 & \multirow{4}{*}{$5.569^{*}$} & \multirow{4}{*}{0.05} \\
\hline & & 167.746 & .777 & 234 & & \\
\hline & Within groups & 183.715 & & 238 & & \\
\hline & Total & & & & & \\
\hline \multirow{4}{*}{$\begin{array}{l}\text { Production and } \\
\text { delivery of } \\
\text { Web-Based } \\
\text { Instruction }\end{array}$} & \multirow{2}{*}{$\begin{array}{l}\text { Between } \\
\text { groups }\end{array}$} & 11.812 & 2.953 & 4 & \multirow{4}{*}{$4.122^{*}$} & \multirow{4}{*}{0.05} \\
\hline & & 164.072 & .716 & 229 & & \\
\hline & Within groups & 175.885 & & 233 & & \\
\hline & Total & & & & & \\
\hline \multirow{4}{*}{$\begin{array}{l}\text { Upgrading } \\
\text { ICT/Educational } \\
\text { Technology } \\
\text { Infrastructure an } \\
\text { Human Resources }\end{array}$} & \multirow{4}{*}{$\begin{array}{l}\text { Between } \\
\text { groups } \\
\text { Within groups } \\
\text { Total }\end{array}$} & 9.673 & 2.423 & 4 & \multirow{4}{*}{$3.454^{*}$} & \multirow{4}{*}{0.05} \\
\hline & & 163.467 & .702 & 233 & & \\
\hline & & 173.160 & & & & \\
\hline & & & & & & \\
\hline \multirow{4}{*}{$\begin{array}{l}\text { Reduction of } \\
\text { drop-out/failure rates } \\
\text { in STM among } \\
\text { female }\end{array}$} & \multirow{4}{*}{$\begin{array}{l}\text { Between } \\
\text { groups } \\
\text { Within groups } \\
\text { Total }\end{array}$} & 20.041 & 5.010 & 4 & \multirow{4}{*}{$7.360^{*}$} & \multirow{4}{*}{0.05} \\
\hline & & 158.598 & .684 & 233 & & \\
\hline & & 178.639 & & 237 & & \\
\hline & & & & & & \\
\hline
\end{tabular}

The results revealed that STEP-B had been effective in building the capacity of staff and the end users of WBLS $\left(\mathrm{F}_{(4,234)}=5.569, \mathrm{p}<0.05\right)$. Thus hypothesis seven was rejected. For production and delivery of WBLS $\left(\mathrm{F}_{(4,229)}=4.122\right.$ $\mathrm{p}<0.0)$ upgrading of ICT, Educational Technology infrastructure and human resources $\left(\mathrm{F}_{(4,233)}=3.454, \mathrm{p}<0.05\right)$ and reduction of drop out/failure rates among females in $\operatorname{STM}\left(\mathrm{F}_{(4,233)}=7.360, \mathrm{P}<0.05\right)$.In view of the results of the data analyzed, all the null hypotheses were rejected

\section{Conclusions}

One can conviniently say that the STEP-B project that was sponsored and financed by the World Bank was very effective in encouraging the use of ICTs in improving the teaching and learning of STM. Not only this, the new approach seems more flexible, robust, user friendly, participatory and active.This is reflected in the improved performance of the target group and reduction in the drop-out/failure rates.It can there fore be concluded that Nigeria and indeed OAU Ile-Ife has joined The Society for Information Technology and Teacher Education (SITE) and the International Society for Technology in Education(ISTE) in their universal vision at applying ICT/Technology in teaching and learning in the $21^{\text {st }}$ Century.Other visions of SITE/ISTE that OAU Ile-Ife in Nigeria has imbibed is interest in the creation and dissemination of research, workshops, training in ICTs using transnational and international collaborations. As a result of the exposure to SITE activities (since 2009 to date), OAU Ile -Ife like SITE has become the best, foremost and the only unique Institution in Nigeria that has encourage and promote the use of ICTs in Education both for education and to solve work place problems. This was the reason why The World Bank adjudged OAU Ife as a Center of Excellence in Information Technology.The contributions of The Carnegie Corporation, World Bank and SITE are therefore acknowledged.

\section{Recommendation}

With respect to future direction of development of STM in Nigeria, it was suggested that similar study should be replicated in the primary school level as this is the foundation. It is also envisaged that this project will consume more fund than at the Post-Basic Education level. However, the effort is going to be rewarding. In addition, greater attention should be paid toward addressing the core challenges i.e. epileptic power out tage, poor maintenance culture and negative attitude to innovation and lack of support. 


\section{References}

Abdullahi, M.D. (1993). Technology and Science reform and development: The Nigeria experience. Education Today, 6(3), 6-8.

Ajewole, G., \& Owolabi, T. (1999). A handbook on science education for tertiary students, Lagos.

Egwu, S.O. (2009). Road map to education sector Federal Ministry of Education Abuja.

Federal Ministry of Education. (2008). National Policy on Education. National Education Research Development Centre.

National Policy on Science and Technology (1998). Federal Ministry of Science and Technology.

Obomanu, B.J., \& Adaramola, M.O. (2011). Factors related to under achievement in Science, Technology and Mathematic Education in secondary schools in River States. Journal of Education, 1(1), 102-110.

Okebukola, P. (2007). Science Technology and Mathematics Education for sustainable development. Keynote Address at Golden Jubilee Anniversary Conference Science Teachers Association of Nigeria (STAN) Sokoto.

Okunola, P.O. (2001). Science and Technology reforms and development: The Nigeria experience, 2(4), 35-59.

Science and Technology Education in Post-Basic Institutions Project (STEP-B 2011). Newsletter published by the Federal Ministry of Education, Abuja.

Togonu-Bickersteth. (2008). A proposal on Science and Technology Education in Post-Basic Education Institutions in Nigeria submitted to the Federal Ministry of Education Abuja.

UNESCO (2009). Strong Foundations Early Childhood Care and Education. EFA Global Monitoring Report, Paris. 